\title{
TRAFFIC EFFECTS ON THE SOIL PRECONSOLIDATION PRESSURE DUE TO EUCALYPTUS HARVEST OPERATIONS
} \author{
Araújo Junior ${ }^{1}$ \\ ${ }^{I}$ UFLA - Depto. de Ciência do Solo, C.P. 3037 - 37200-000 - Lavras, MG - Brasil. \\ Celulose Nipo-Brasileira S.A - 35195-000 - Belo Oriente, MG - Brasil. \\ *Corresponding author <msouzadj@ufla.br>
}

Moacir de Souza Dias Junior ${ }^{1 *}$; Fernando Palha Leite²; Edson Lasmar Júnior ${ }^{1}$; Cezar Francisco

\begin{abstract}
One of the limitations for reaching sustainable forest development is related to the traffic of machines and vehicles during harvest operations and wood transport, which may cause soil structure degradation. Seeking a way to analyze this problem, the objective of this study was to determine the traffic effects due to harvest operations and wood transport, on the preconsolidation pressure $\left(\sigma_{p}\right)$ in a Typic Acrustox cultivated with eucalyptus. This study was conducted using undisturbed soil samples collected at the 0.1$0.125 \mathrm{~m}$ depth. Undisturbed soil samples were used in the uniaxial compression tests. Soil sampling consisted of two stages, before and after the mechanized harvest operations. The traffic effects on the $\sigma_{p}$ in the dry season indicated that the soil compaction process was neither evident nor important. However, in the rainy season the traffic effects on the $\sigma_{\mathrm{p}}$ indicated that the operations performed with Harvester and Forwarder caused greater soil compaction than those with Motorized Saw and Manual, which caused less soil compaction. Key words: forest soil compaction, soil structure, uniaxial compression test
\end{abstract}

\section{EFEITO DO TRÁFEGO NAS PRESSÕES DE PRECONSOLIDAÇÃO DO SOLO DEVIDO AS OPERAÇÕES DE COLHEITA DO EUCALYPTUS}

\begin{abstract}
RESUMO: Uma das limitações para alcançar o desenvolvimento florestal sustentável está relacionado ao tráfico de máquinas e veículos durante as operações de colheita e transporte de madeira que podem causar degradação da estrutura do solo. Buscando uma maneira para analisar este problema, o objetivo deste estudo foi determinar o efeito do tráfego devido a operações de colheita e transporte de madeira, nas pressões de preconsolidação $\left(\sigma_{\mathrm{p}}\right)$ de um Latosol Vermelho-Amarelo, cultivado com Eucalyptus. Este estudo foi realizado usando amostras de solo indeformadas coletadas a 0,10-0,125 $\mathrm{m}$ de profundidade. As amostras indeformadas foram usadas nos ensaios de compressão de uniaxial. A amostragem consistiu de duas fases, antes e depois das operações de colheita mecanizada. As alterações causadas pelo tráfego nas $\sigma_{p}$ na estação seca indicaram que o processo de compactação não foi evidente e nem importante. Já na estação chuvosa as alterações causadas nas $\sigma_{p}$ pelas operações realizadas com o Harvester e Forwarder foram as que causaram maior compactação, enquanto que as operações realizadas com a Motosserra e baldeio manual, foram as que causaram menor compactação do solo.

Palavras-chave: compactação de solos florestais, estrutura do solo, ensaio de compressão uniaxial
\end{abstract}

\section{INTRODUCTION}

Soil compaction has been identified as one of the major problems causing soil degradation (Canillas \& Salokhe, 2002, Horn et al., 2003). Thus, one of the limitations for reaching sustainable forest development is related to the traffic of machines and vehicles during the harvest operations and wood transport, which may cause soil compaction (Dias Junior et al., 1999). Soil compaction can occur due to the fact that during mechanized operations, there is neither control of the soil moisture nor of the soil bearing capacity. This situation can become more critical due to the indiscriminate traffic in the area which can result in enhanced soil compaction spread over years causing, as a consequence, a reduction of the productivity (Dias Junior et al., 1999).

Soil compaction susceptibility may limit the execution of mechanized operations under wet conditions (Dias Junior et al., 2002, Arvidsson, 2003). Thus, it becomes important to determine the soil moisture at which it can be submitted to harvest operations and wood transport, as well as, to quantify damages caused to soil structure, when the applied pressures exceed soil bearing capacity (Dias Junior \& Pierce, 1996). Therefore, the sustainable forest development is related to the traffic of the harvest operations and wood transport (Dias Junior et al., 2003), and the scheduling of this traffic 
would contribute to minimize soil compaction and consequently, the losses of productivity of areas under intense traffic.

Considering that the preconsolidation pressure is an indicator of soil strength (Arvidsson, 2001, Horn \& Fleige, 2003) and of the maximum pressure that should be applied to a soil in order to avoid soil compaction (Gupta et al., 1989; Lebert \& Horn, 1991; Defossez \& Richard, 2002), the objective of this study was to determine the traffic effects of harvest operations and wood transport through the preconsolidation pressure determined for a Typic Acrustox during the harvest of an eucalyptus plantation.

\section{MATERIAL AND METHODS}

This study was carried out in experimental areas cultivated with eucalyptus located in Peçanha (Buriti, Dourado and São Leonardo Projects) $42^{\circ} 33^{\prime} 45^{\prime \prime}$ W; $18^{\circ} 32^{\prime} 44^{\prime \prime}$ S, Sabinópolis (Imbaúbas Project) 4304'55" W; 18³9'59" S, Guanhães (Aeroporto Project), Belo Oriente (Água Suja encosta, Água Suja baixada, Cajá encosta, Cajá baixada Projects) 42 $56^{\prime} 04^{\prime \prime} \mathrm{W} ; 1^{\circ} 46^{\prime} 30^{\prime \prime}$ $\mathrm{S}$ and Santa Bárbara (Carlos Hosken encosta Project) 4324'47" W; 1957’39" S, Counties, MG, Brazil. Soils at all sites were classified as Typic Acrustox (Soil Taxonomy) or Orthic Ferralsol (FAO). Textural classes are presented in Table 1.

The areas in this study were at the end of the first cultivation cycle with eucalyptus. The tree ages were 7.0 years in the Imbaúbas, Cajá Baixada, Cajá Encosta Projects, 8.0 years in the Água Suja baixada, Água Suja Encosta and Carlos Hosken Projects, 9.6 years in the Buriti Project, 10.6 years in the Dourado Project, 12.6 years in the São Leonardo Project, and 15.2 years in the Aeroporto Project.

Machines used for forest harvest operations and wood transport were: Feller Büncher, model 2618 with tracks, applied pressure $\mathrm{P}=45 \mathrm{kPa}$, and Skidder (Tires

Table 1 - Particle size distribution of the Typic Acrustox (Orthic Ferralsol).

\begin{tabular}{llrrl}
\hline Project & Clay & \multicolumn{1}{c}{ Silt } & Sand & Soil textural Class \\
\hline & ----- & g kg $^{-1}$ & ----- & \\
Buritis & $500^{1}$ & 80 & 420 & Clay \\
Dourado & 500 & 90 & 410 & Clay \\
São Leonardo & 400 & 90 & 510 & Sandy clay \\
Imbaúbas & 550 & 90 & 360 & Clay \\
Aeroporto & 660 & 130 & 210 & Clay \\
Água Suja Encosta & 630 & 50 & 320 & Clay \\
Água Suja Baixada & 300 & 130 & 570 & Sandy clay loam \\
Cajá Encosta & 620 & 70 & 310 & Clay \\
Cajá Baixada & 200 & 150 & 650 & Sandy clay loam \\
$\begin{array}{l}\text { Carlos Hosken } \\
\text { Encosta }\end{array}$ & 510 & 120 & 370 & Clay \\
\hline
\end{tabular}

${ }^{1}$ Average of three replications.
30.5L.32) with tires $4 \times 4$, model $460, \mathrm{P}=115 \mathrm{kPa}$; Harvester with tires $6 \times 6$ model $1270, \mathrm{P}=70 \mathrm{kPa}$, and Forwarder with tires $8 \times 8$, model $1710, \mathrm{P}=105 \mathrm{kPa}$, Clambunk model 1710, $\mathrm{P}=60 \mathrm{kPa}$. The applied pressures $\mathrm{P}$ were extracted from the machine operation manuals. Soil sampling consisted of two stages:

\section{Before harvest operations}

To obtain the bearing capacity model, undisturbed soil samples ( $0.064 \mathrm{~m}$ of diameter and $0.0254 \mathrm{~m}$ of height) were collected at $0.10-0.125 \mathrm{~m}$ depth, summing up thirtysix samples for projects: Buriti, Dourado and São Leonardo, forty-eight for Imbaúbas, and twenty for: Água Suja Encosta, Água Suja baixada, Cajá Encosta, Cajá baixada and Carlos Hosken Encosta. The undisturbed soil samples of the projects Buriti, Dourado and São Leonardo were collected in the dry season and of the projects Aeroporto, Água Suja baixada, Água Suja Encosta, Cajá Baixada, Cajá Encosta, Carlos Hosken and Imbaúbas in the rainy season. Soil sampling was performed at this depth due to its highest penetration resistance.

These undisturbed soil samples were initially saturated in a tray with water up to $2 / 3$ of the sample height for 24 hours and air dried in laboratory until the moisture content was in the range of 0.02 to $0.69 \mathrm{~kg} \mathrm{~kg}^{-1}$ and then used in the uniaxial compression test (Bowles, 1986). For the uniaxial compression tests the undisturbed soil samples were kept within the coring cylinders, which were placed into the compression cell and subsequently subjected to pressures 25, 50, 100, 200, 400, 800 and 1.600 $\mathrm{kPa}$. Each pressure was applied until $90 \%$ of the maximum deformation was reached and then the pressure was increased to the next level. The $90 \%$ of maximum deformation was determined by drawing a straight line through the data points of the initial part of the curve obtained when dial readings were plotted versus square root of the time, until this line intercepts the y axis (dial readings). A second straight line was drawn from this intersection with all abscissas 1.15 time as large as corresponding values on the first line. The intersection of this second line and the laboratory curve is the point corresponding to $90 \%$ consolidation (Taylor, 1948). From the soil compression curves the preconsolidation pressures $\left(\sigma_{\mathrm{p}}\right)$ were determined as a function of the moisture content (U) (Dias Junior \& Pierce, 1995). Then, the regression analyses were accomplished using the software Sigma Plot 4.0 (Jandel Scientific) to obtain the bearing capacity model, which is the adjustment of $\sigma_{p}$ as a function of $U$. After that the comparison of the regression equations was made using the procedure described in Snedecor \& Cochran (1989).

\section{After harvest operations and wood transport}

To quantify the traffic effect due to harvest operations and wood transport on $\sigma_{p}$, undisturbed soil samples of the same size as before were collected at 
0.10-0.125 $\mathrm{m}$ depth in $1999,2000,2001$, and 2003, according to Table 2, and submitted to the uniaxial compression test as made previously (Bowles, 1986) with the moisture content at which the soil samples were collected (Table 3). The undisturbed soil samples were involved in plastic, coated with paraffin and then stored at room temperature. After the completion of the uniaxial compression test, $\sigma_{p}$ was obtained according Dias Junior \& Pierce (1995) and the moisture content according Gardner (1986), and plotted as shown in Figure 2.

Table 2 - Number of undisturbed soil samples collected at the $0.10-0.125 \mathrm{~cm}$ depth in a Typic Acrustox after harvest operations and wood transport from 1999 to 2003.

\begin{tabular}{|c|c|c|c|c|c|c|c|c|c|c|c|c|c|c|}
\hline \multirow[t]{2}{*}{ Project } & \multicolumn{2}{|c|}{$\mathrm{F}$ and $\mathrm{S}^{1}$} & \multicolumn{2}{|c|}{$\mathrm{F}$ and $\mathrm{S} \mathrm{II}^{2}$} & \multicolumn{2}{|c|}{$\mathrm{H}$ and $\mathrm{F}^{3}$} & \multirow{2}{*}{\multicolumn{2}{|c|}{$\mathrm{M}$ and $\mathrm{F}^{4}$}} & \multirow{2}{*}{\multicolumn{2}{|c|}{$\mathrm{F}$ and $\mathrm{C}^{5}$}} & \multirow{2}{*}{\multicolumn{2}{|c|}{$\mathrm{M}$ and $\mathrm{M}^{6}$}} & \multicolumn{2}{|c|}{$\mathrm{PA}^{7}$} \\
\hline & 1999 & 2003 & 1999 & 2003 & 1999 & 2003 & & & & & & & & \\
\hline & \multicolumn{14}{|c|}{ Dry season } \\
\hline Buriti & 12 & 5 & 12 & 5 & 12 & 5 & & & & & & & & \\
\hline Dourado & 12 & 5 & 12 & 5 & 12 & 5 & & & & & & & & \\
\hline \multirow[t]{3}{*}{ S.Leonardo } & 12 & 5 & 12 & 5 & 12 & 5 & & & & & & & & \\
\hline & \multicolumn{14}{|c|}{ Rainy season } \\
\hline & 2000 & 2003 & & & 2000 & 2003 & 2000 & 2003 & & & & & 2000 & 2003 \\
\hline Imbaúbas & 24 & 5 & & & 24 & 5 & 16 & 5 & & & & & 25 & 5 \\
\hline \multirow[t]{2}{*}{ Aeroporto } & 12 & 5 & & & 12 & 5 & 12 & 5 & & & & & & 5 \\
\hline & 2001 & 2003 & & & & & 2001 & 2003 & 2001 & 2003 & 2001 & 2003 & 2001 & 2003 \\
\hline Água Suja Encosta & 4 & 5 & & & & & 4 & 5 & 4 & 5 & 4 & 5 & 4 & 5 \\
\hline Água Suja Baixada & 4 & 5 & & & & & 4 & 5 & 4 & 5 & & & 4 & 5 \\
\hline Cajá Encosta & 4 & 5 & & & & & 4 & 5 & 4 & 5 & 4 & 5 & 4 & \\
\hline Cajá Baixada & 4 & 5 & & & & & 4 & 5 & 4 & 5 & 4 & 5 & 4 & 5 \\
\hline C. Hosken Encosta & 4 & 5 & & & & & 4 & 5 & 4 & 5 & 4 & 5 & 4 & 5 \\
\hline
\end{tabular}

1- F and $\mathrm{S}=$ Feller and Skidder 30.5L.32, 2- F and S II = Feller and Skidder 66.43.00.26, 3- $\mathrm{H}$ and F = Harvester and Forwarder, 4- $\mathrm{M}$ and $\mathrm{F}=$ Motorized Saw and Forwarder, 5- F and $\mathrm{C}=$ Feller and Clambunk, 6- $\mathrm{M}$ and $\mathrm{M}=$ Motorized Saw and Manual, 7- PA $=$ Processing Area.

Table 3 - Moisture content at which the soil samples were collected in a Typic Acrustox at the 0.10-0.125 m depth after harvest operations and wood transport.

\begin{tabular}{|c|c|c|c|c|c|c|c|}
\hline \multirow{2}{*}{ Project } & $\mathrm{F}$ and $\mathrm{S}^{8}$ & $\mathrm{~F}$ and $\mathrm{S}^{9}$ & $\mathrm{H}$ and $\mathrm{F}^{10}$ & $\mathrm{M}$ and $\mathrm{F}^{11}$ & $\mathrm{~F}$ and $\mathrm{C}^{12}$ & $\mathrm{M}$ and $\mathrm{M}^{13}$ & $\mathrm{PA}^{14}$ \\
\hline & \multicolumn{7}{|c|}{ Moisture Content $\left(\mathrm{kg} \mathrm{kg}^{-1}\right)$} \\
\hline & \multicolumn{7}{|c|}{2001} \\
\hline Buriti & $0.29^{1}$ & $0.30^{1}$ & $0.28^{1}$ & - & - & - & - \\
\hline Dourado & $0.35^{1}$ & $0.35^{1}$ & $0.35^{1}$ & - & - & - & - \\
\hline S.Leonardo & $0.28^{1}$ & $0.28^{1}$ & $0.29^{1}$ & - & - & - & - \\
\hline Imbaúbas & $0.33^{2}$ & - & $0.32^{2}$ & $0.33^{3}$ & - & - & $0.29^{5}$ \\
\hline Aeroporto & $0.38^{1}$ & - & $0.36^{1}$ & $0.33^{4}$ & - & - & - \\
\hline Água Suja Encosta & $0.26^{6}$ & - & - & $0.26^{6}$ & $0.25^{6}$ & $0.25^{6}$ & $0.25^{6}$ \\
\hline Água Suja Baixada & $0.18^{6}$ & - & - & $0.21^{6}$ & $0.23^{6}$ & - & $0.16^{6}$ \\
\hline Cajá Encosta & $0.31^{6}$ & - & - & $0.27^{6}$ & $0.30^{6}$ & $0.29^{6}$ & $0.30^{6}$ \\
\hline Cajá Baixada & $0.24^{6}$ & - & - & $0.22^{6}$ & $0.23^{6}$ & $0.22^{6}$ & $0.15^{6}$ \\
\hline \multirow[t]{2}{*}{ Carlos Hosken Encosta } & $0.29^{6}$ & - & - & $0.28^{6}$ & $0.28^{6}$ & $0.28^{6}$ & $0.29^{6}$ \\
\hline & \multicolumn{7}{|c|}{2003} \\
\hline Buriti & $0.30^{1}$ & $0.30^{1}$ & $0.29^{1}$ & $0.30^{1}$ & - & - & - \\
\hline Dourado & $0.34^{1}$ & $0.34^{1}$ & $0.33^{1}$ & - & - & - & - \\
\hline S.Leonardo & $0.29^{1}$ & $0.28^{1}$ & $0.28^{1}$ & $0.31^{1}$ & - & - & - \\
\hline Imbaúbas & $0.29^{2}$ & - & $0.27^{2}$ & $0.30^{3}$ & - & - & $0.24^{5}$ \\
\hline Aeroporto & $0.37^{1}$ & - & $0.37^{1}$ & $0.37^{4}$ & - & - & $0.37^{7}$ \\
\hline Água Suja Encosta & $0.26^{7}$ & - & - & $0.26^{7}$ & $0.24^{7}$ & $0.26^{7}$ & $0.24^{7}$ \\
\hline Água Suja Baixada & $0.17^{7}$ & - & - & $0.18^{7}$ & $0.16^{7}$ & - & $0.12^{7}$ \\
\hline Cajá Encosta & $0.23^{7}$ & - & - & $0.25^{7}$ & $0.29^{7}$ & $0.24^{7}$ & - \\
\hline Cajá Baixada & $0.20^{7}$ & - & - & $0.18^{7}$ & $0.18^{7}$ & $0.19^{7}$ & $0.17^{7}$ \\
\hline Carlos Hosken Encosta & $0.29^{7}$ & - & - & $0.29^{7}$ & $0.23^{7}$ & $0.31^{7}$ & $0.25^{7}$ \\
\hline
\end{tabular}

1- Average of 12 replications, 2- Average of 24 replications, 3- Average of 16 replications, 4- Average of 11 replications, 5- Average of 25 replications, 6- Average of 4 replications, 7- Average of 5 replications,- indicated that no measurement was done, 8- F and $\mathrm{S}=$ Feller Büncher (2618 with crawler) and Skidder with tires 30.5L.32, 9- F and S II = Feller Büncher (2618 with crawler) and Skidder (460 with tires 66.43.00.26), $10-\mathrm{H}$ and $\mathrm{F}=$ Harvester $(1270$ with tires $700 \times 26.5)$ and Forwarder $(1710$ with tires $750 \times 26.5), 11-\mathrm{M}$ and $\mathrm{F}=$ Motorized saw and Forwarder $(636$ with tires $650 \times 26.5), 12-\mathrm{F}$ and $\mathrm{C}=$ Feller and Clambunk, $13-\mathrm{M}$ and $\mathrm{M}=\mathrm{Motorized} \mathrm{Saw} \mathrm{and}$ Manual, 14 - PA = Processing Area. 


\section{RESULTS AND DISCUSSION}

The harvest operations accomplished at the rainy season caused more increases in the initial soil bulk density than those accomplished in the dry season, mainly in the wood processing areas during 2001 and 2003 (Table 4 and 5) indicating the importance of the moisture control at the time of the harvest operations.

The undisturbed soil samples collected before harvest operations were used to obtain the bearing capacity model of the Typic Acrustox which was of the type $\sigma_{\mathrm{p}}=10^{(\mathrm{a}+\mathrm{bu})}$, with $\mathrm{R}^{2}$ significant at $1 \%$. The estimated " $\mathrm{a}$ " and " $\mathrm{b}$ " values varied from 2.65 to 2.84 , and from -

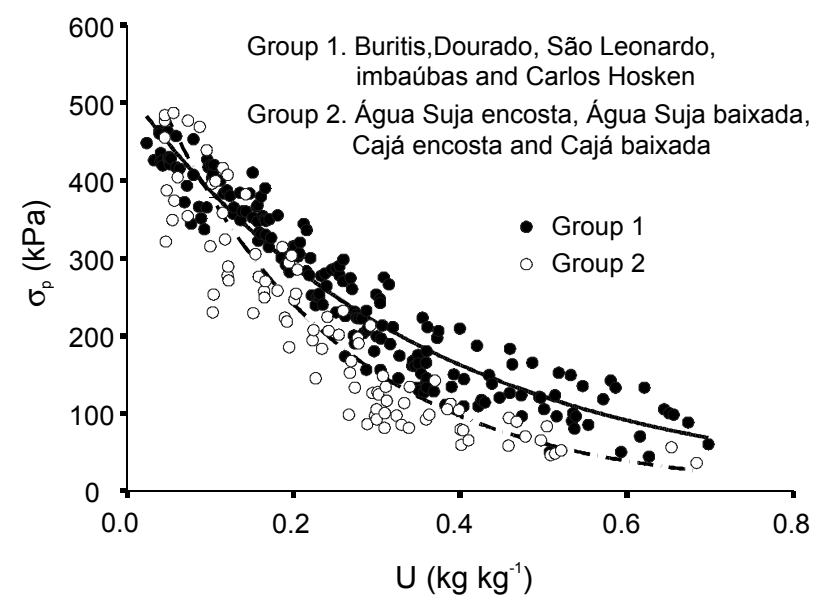

Figure 1 - Bearing Capacity Models of the Typic Acrustox under eucalyptus at 0.10-0.125 m depth, obtained using undisturbed soil samples collected before harvest operations.
1.03 to -2.76 , respectively (Table 6 ). The type of equations was the same as Dias Junior (1994) and Dias Junior \& Pierce (1996).

The homogeneity tests of the equations (Snedecor $\&$ Cochran, 1989) indicated that there were two homogeneous data groups. For the data of homogeneous models, a new equation was adjusted for $\left(\mathrm{U}, \sigma_{\mathrm{p}}\right)$, obtaining only one equation of $\sigma_{p}$ as a function of $U$ (Table 6) for each group. The two final equations, which are the bearing capacity models of the Typic Acrustox, are shown in Figure 1 and Table 7. Equation 1was used to evaluate the traffic effects on the Buriti, Dourado, São Leonardo, Imbaúbas and Carlos Hosken soils, and equation 2 was

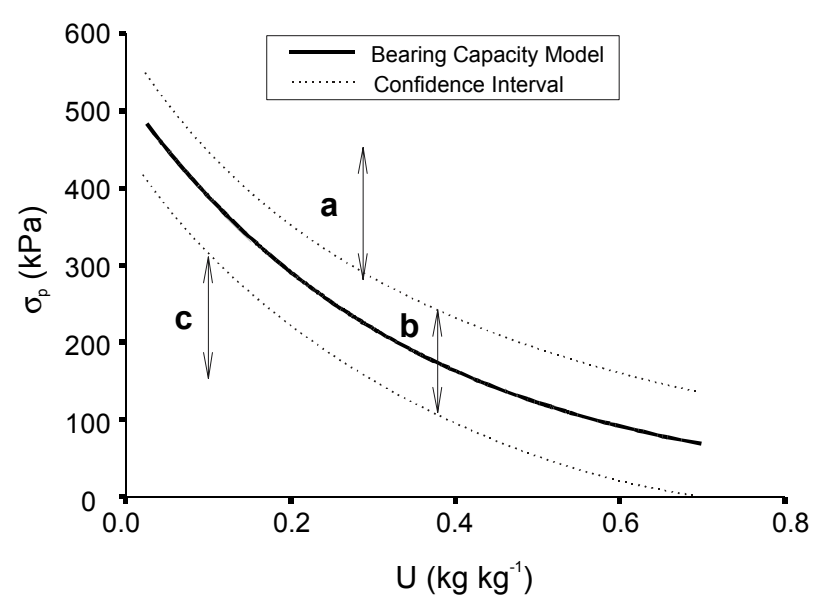

Figure 2 - Criteria used to analyze the effect of harvest operations and wood transport on the preconsolidation pressure of the Typic Acrustox under eucalyptus at $0.10-0.125 \mathrm{~m}$ depth.

Table 4 - Bulk density before (Dsi) and after (Dst) the harvest operations for of a Typic Acrustox at 0.10-0.125 m depth. 2001.

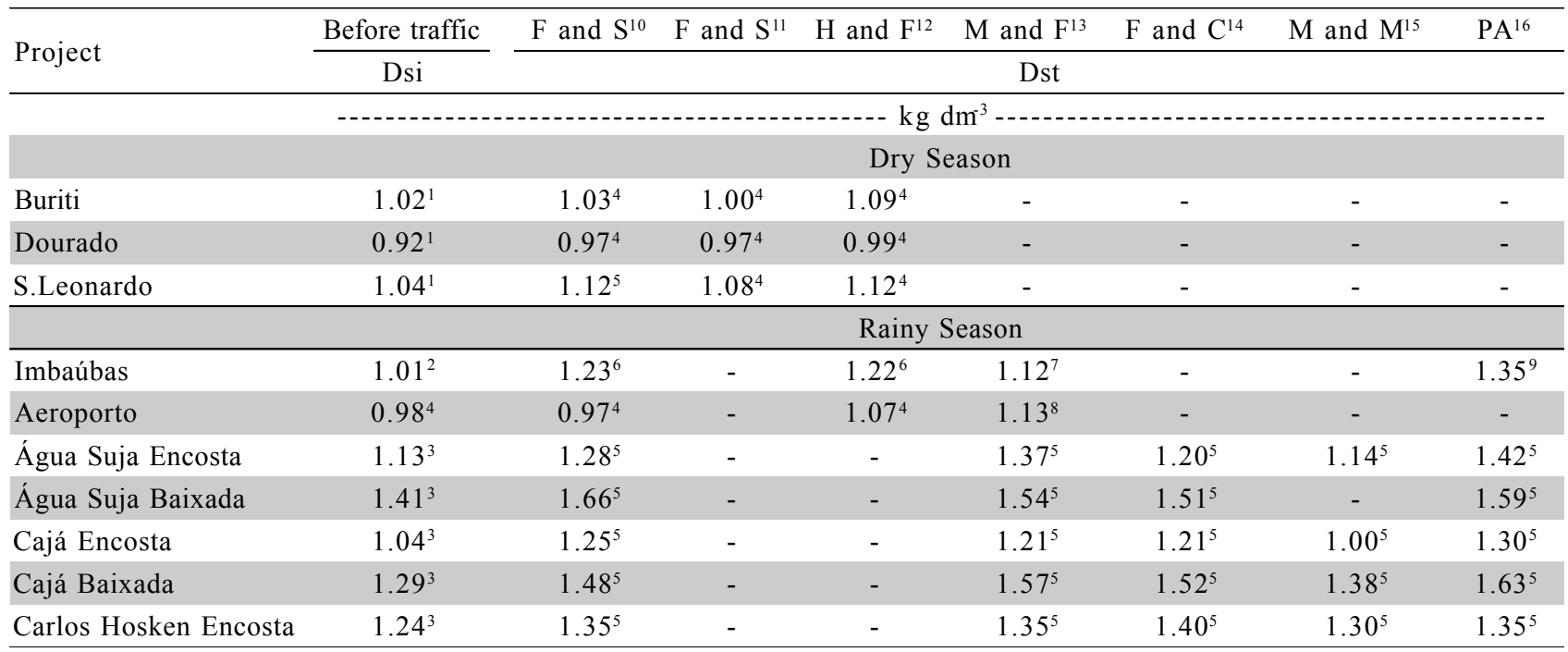

1- Average of 36 replications, 2- Average of 48 replications, 3- Average of 20 replications, 4- Average of 12 replications, 5- Average of 4 replications, 6- Average of 24 replications, 7- Average of 16 replications, 8 - Average of 11 replications, 9- Average of 25 replications and - indicated that no measurement was done, $10-\mathrm{F}$ and $\mathrm{S}=$ Feller Büncher (2618 with crawler) and Skidder with tires $30.5 \mathrm{~L} .32,11-\mathrm{F}$ and S II = Feller Büncher (2618 with crawler) and Skidder (460 with tires 66.43.00.26), 12- $\mathrm{H}$ and $\mathrm{F}=$ Harvester $(1270$ with tires $700 \times 26.5)$ and Forwarder $(1710$ with tires $750 \times 26.5), 13-\mathrm{M}$ and $\mathrm{F}=$ Motorized saw and Forwarder $(636$ with tires $650 \times 26.5), 14-\mathrm{F}$ and $\mathrm{C}=\mathrm{Feller}$ and Clambunk, 15- $\mathrm{M}$ and $\mathrm{M}=$ Motorized Saw and Manual, $16-\mathrm{PA}=$ Processing Area. 
used for Água Suja encosta, Água Suja baixada, Cajá encosta and Cajá baixada.

In agriculture, the application of pressures larger than the largest pressure applied previously to the soil should be avoided in order to eliminate additional soil compaction (Gupta et al., 1989; Lebert \& Horn, 1991; Imhoff et al., 2001). Considering that the preconsolidation pressure is an indicative of the maximum applied pressure to the soil in the past (Holtz \& Kovacs, 1981; Dias Junior, 1994), Figure 1 was then divided into three regions to evaluate the traffic effects according to Dias Junior (2003). The considered regions (Figure 2) are: a) the region where the preconsolidation pressure values determined after the traffic are larger than the higher limit of the confidence interval, being considered as the region with additional soil compaction; b) the region where preconsolidation pressures determined after the traffic are between the higher and lower limits of the confidence intervals. Although, the soil samples in this region did not suffer soil compaction, this region indicates the soil samples that might suffer soil compaction in the next harvest operations if the applied pressures are larger than the higher limit of the confidence interval, and c) a region where the preconsolidation pressure values determined after the traffic are smaller than the lower limit of the confidence interval.

According to the equation $\sigma_{p}=10^{(2.71-1.26 \mathrm{U})}$, the operations accomplished with Feller Büncher and Skidder with tires 66.43.00.26 in the dry season of 1999 (Table 8 ) presented in average a slight percentage of soil samples $(8.3 \%)$ with larger preconsolidation pressure values de- termined after the traffic in the region with additional soil compaction, in relation to the Feller Büncher and Skidder with tires 30.5L.32 (2.7\%) and Harvester and Forwarder $(5.7 \%)$. The low percentages can be explained by the fact that in the dry season the soil presents a higher resistance to compression and higher bearing capacity and therefore, the soil compaction processes were not evident (Dias Junior, 2000). However, in the Dourado Project, those machine groups caused greater soil compaction than in the Buritis and São Leonardo Projects, indicating that changes in the harvest operation strategy should be considered.

In the rainy season, the operations accomplished with Harvester and Forwarder (Table 9) were the ones that presented larger percentage of soil samples $(33.5 \%)$ with preconsolidation pressure values determined after the traffic in the region with additional soil compaction, followed by the Processing Area (18.9\%), being therefore, those operations the ones that caused greater soil compaction. The Aeroporto Project presented the highest percentage of soil samples $(58 \%)$ with preconsolidation pressure values in the region with additional soil compaction (Table 9). Although the operations made with Harvester and Forwarder caused greater soil compaction in the rainy season, one might consider that the traffic with those machines is spatially restricted avoiding, therefore, the dissemination of the soil compaction in the whole area.

On the other hand, all operations accomplished in the dry and rainy season in 1999, 2000 and 2001 caused a high percentage of soil samples with preconsolidation pressure values located in the region

Table 5 - Bulk density before (Dsi) and after (Dst) harvest operations for of a Typic Acrustox at 0.10-0.125 m depth. 2003.

\begin{tabular}{|c|c|c|c|c|c|c|c|c|}
\hline \multirow{2}{*}{ Project } & \multirow{2}{*}{$\frac{\text { Before traffic }}{\text { Dsi }}$} & \multicolumn{2}{|c|}{$\mathrm{F}$ and $\mathrm{S}^{5} \mathrm{~F}$ and $\mathrm{S} \mathrm{II}^{6}$} & \multirow{2}{*}{$\mathrm{H}$ and $\mathrm{F}^{7}$} & \multirow{2}{*}{$\begin{array}{c}\mathrm{M} \text { and } \mathrm{F}^{8} \\
\text { Dst }\end{array}$} & \multirow[t]{2}{*}{$\mathrm{F}$ and $\mathrm{C}^{9}$} & \multirow[t]{2}{*}{$\mathrm{M}$ and $\mathrm{M}^{10}$} & \multirow[t]{2}{*}{$\mathrm{PA}^{11}$} \\
\hline & & \multicolumn{2}{|c|}{ 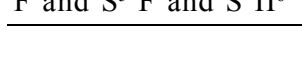 } & & & & & \\
\hline & \multirow{2}{*}{\multicolumn{7}{|c|}{ Dry season }} & $\cdots-1$ \\
\hline & & & & & & & & \\
\hline Buritis & $1.02^{1}$ & $1.03^{1}$ & $1.05^{1}$ & $1.13^{1}$ & $1.05^{1}$ & - & - & - \\
\hline Dourado & $0.92^{1}$ & $0.88^{1}$ & $0.95^{1}$ & $0.99^{1}$ & - & - & - & - \\
\hline S.Leonardo & $1.04^{1}$ & $1.04^{1}$ & $1.14^{1}$ & $1.14^{1}$ & $1.10^{1}$ & - & - & - \\
\hline \multirow[t]{2}{*}{ Imbaúbas } & $1.01^{2}$ & $1.22^{2}$ & - & $1.29^{2}$ & $1.25^{2}$ & - & - & $1.31^{2}$ \\
\hline & & \multicolumn{6}{|c|}{ Rainy season } & \\
\hline Aeroporto & $0.98^{4}$ & $1.02^{4}$ & - & $1.04^{4}$ & $1.03^{4}$ & - & - & $1.05^{4}$ \\
\hline Água Suja Encosta & $1.13^{3}$ & $1.31^{3}$ & - & - & $1.21^{3}$ & $1.30^{3}$ & $1.11^{3}$ & $1.51^{3}$ \\
\hline Água Suja Baixada & $1.41^{3}$ & $1.61^{3}$ & - & - & $1.59^{3}$ & $1.68^{3}$ & - & $1.64^{3}$ \\
\hline Cajá Encosta & $1.04^{3}$ & $1.28^{3}$ & - & - & $1.14^{3}$ & $1.14^{3}$ & $1.01^{3}$ & - \\
\hline Cajá Baixada & $1.29^{3}$ & $1.53^{3}$ & - & - & $1.55^{3}$ & $1.53^{3}$ & $1.27^{3}$ & $1.56^{3}$ \\
\hline Carlos Hosken Encosta & $1.24^{3}$ & $1.26^{3}$ & - & - & $1.20^{3}$ & $1.38^{3}$ & $1.11^{3}$ & $1.35^{3}$ \\
\hline
\end{tabular}

1- Average of 36 replications, 2- Average of 48 replications, 3- Average of 20 replications, 4- Average of 24 replications, - indicated that no measurement was done, 5- F and $\mathrm{S}=$ Feller Büncher (2618 with crawler) and Skidder with tires 30.5L.32, 6- F and $\mathrm{S}$ II $=$ Feller Büncher (2618 with crawler) and Skidder (460 with tires 66.43.00.26), 7- $\mathrm{H}$ and F $=$ Harvester $(1270$ with tires $700 \times 26.5)$ and Forwarder $(1710$ with tires $750 \times 26.5), 8-\mathrm{M}$ and $\mathrm{F}=$ Motorized saw and Forwarder $(636$ with tires $650 \times 26.5)$, 9- $\mathrm{F}$ and $\mathrm{C}=$ Feller and Clambunk, $10-\mathrm{M}$ and $\mathrm{M}=$ Motorized Saw and Manual, 11- PA = Processing Area. 
Table 6 - Parameters of the bearing capacity model $\left(\sigma_{p}=10^{(a+b u)}\right)$, with respective determination coefficients $\left(\mathrm{R}^{2}\right)$, and number of undisturbed soil samples (n) collected at $0.10-0.125 \mathrm{~cm}$ depth in a Typic Acrustox, before harvest operations and comparison of those models (F) according to Snedecor \& Cochran (1989).

\begin{tabular}{|c|c|c|c|c|c|}
\hline Project & A & $\mathrm{b}$ & $\mathrm{R}^{2}$ & $\mathrm{n}$ & $\mathrm{F}$ \\
\hline Buriti & 2.71 & -1.36 & $0.97 * *$ & 34 & \\
\hline Dourado & 2.70 & -1.03 & $0.95 * *$ & 34 & \\
\hline São Leonardo & 2.76 & -1.52 & $0.95 * *$ & 34 & \\
\hline Buriti $\times$ Dourado & & & & & Homogeneous \\
\hline Buriti $\times$ São Leonardo & & & & & Homogeneous \\
\hline Dourado $\times$ São Leonardo & & & & & Homogeneous \\
\hline Buriti, Dourado, São Leonardo & 2.72 & -1.29 & $0.93 * *$ & 102 & \\
\hline Imbaúbas & 2.71 & -1.35 & $0.92 * *$ & 45 & \\
\hline Buriti, Dourado, São Leonardo $\times$ Imbaúbas & & & & & Homogeneous \\
\hline Buriti, Dourado, São Leonardo, Imbaúbas & 2.72 & -1.31 & $0.92 * *$ & 147 & \\
\hline Água Suja Encosta & 2.74 & -1.80 & $0.92 * *$ & 20 & \\
\hline Água Suja Baixada & 2.84 & -2.00 & $0.96 * *$ & 20 & \\
\hline Água Suja Encosta $\times$ Água Suja Baixada & & & & & Homogeneous \\
\hline Água Suja Encosta, Água Suja Baixada & 2.79 & -1.91 & $0.92 * *$ & 40 & \\
\hline Cajá Encosta & 2.65 & -1.78 & $0.93 * *$ & 18 & \\
\hline Cajá Baixada & 2.78 & -2.76 & $0.96^{* *}$ & 19 & \\
\hline Cajá Encosta $\times$ Cajá Baixada & & & & & Homogeneous \\
\hline Cajá Encosta, Cajá Baixada & 2.72 & -2.24 & $0.92 * *$ & 37 & \\
\hline \multicolumn{6}{|l|}{ Cajá Encosta, Cajá Baixada } \\
\hline Água Suja Encosta, Água Suja Baixada $\times$ & & & & & Homogeneous \\
\hline \multicolumn{6}{|l|}{ Cajá Encosta, Cajá Baixada } \\
\hline Água Suja Encosta, Água Suja Baixada, & 2.75 & -1.99 & $0.96 * *$ & 77 & \\
\hline \multicolumn{6}{|l|}{ Cajá Encosta, Cajá Baixada } \\
\hline Carlos Hosken Encosta & 2.68 & -1.14 & $0.92 * *$ & 19 & \\
\hline $\begin{array}{l}\text { Carlos Hosken Encosta } \times \text { Água Suja Encosta,Água Suja Baixada, } \\
\text { Cajá Encosta, Cajá Baixada }\end{array}$ & & & & & Not homogeneous \\
\hline Carlos Hosken Encosta $\times$ Buriti, Dourado, & & & & & Homogeneous \\
\hline \multicolumn{6}{|l|}{ São Leonardo, Imbaúbas, } \\
\hline Buriti, Dourado, São Leonardo, Imbaúbas,Carlos Hosken Encosta & 2.71 & -1.26 & $0.92 * *$ & 166 & \\
\hline $\begin{array}{l}\text { Buriti, Dourado, São Leonardo, Imbaúbas, Carlos Hosken Encosta } \\
\times \text { Água Suja Encosta, Água Suja Baixada, Cajá Encosta, Cajá } \\
\text { Baixada }\end{array}$ & & & & & Not homogeneous \\
\hline
\end{tabular}

Table 7 - Coefficients "a" and " $b$ " of the equation $\sigma_{p}=10^{(a+b u)}$, standard error and $\mathrm{p}$ values.

\begin{tabular}{cccc}
\hline & Coefficient & Standard Error & $\mathrm{p}$ \\
\hline \multicolumn{4}{c}{$\begin{array}{c}\text { Buriti, Dourado, São Leonardo, Imbaúbas and } \\
\text { Carlos Hosken }(\mathrm{n}=166)\end{array}$} \\
$\mathrm{a}$ & 2.71 & 0.0065 & $<0.0001$ \\
$\mathrm{~b}$ & -1.26 & 0.0323 & $<0.0001$ \\
& Água Suja encosta, Água Suja baixada, Cajá \\
encosta and Cajá baixada $(\mathrm{n}=77)$
\end{tabular}

where the preconsolidation pressure values determined after the traffic are between the higher and lower limits of the confidence intervals (Tables 8 and 9). This region is important because it shows the possibility of soil compaction to occur in the next mechanized operation, if the bearing capacity and the appropriated soil moisture content are not considered in operation planning.

In addition, the operations accomplished in 1999 with the Feller Büncher and Skidder with tires 30.5L.32 $(14 \%)$, and with Harvest and Forwarder (14\%) in the dry season, and with Motorized Saw and Manual (18.7\%) in the rainy season of 2001 presented a higher percentage of soil samples with preconsolidation pressure val-

Sci. Agric. (Piracicaba, Braz.), v.62, n.3, p.248-255, May/June 2005 
Table 8 - Classification of the soil samples according Figure 2, using the preconsolidation pressure values determined after the harvest operations for a Typic Acrustox at 0.10-0125 m depth (Dry Season).

\begin{tabular}{|c|c|c|c|c|c|c|}
\hline \multirow[t]{2}{*}{ Project } & \multicolumn{2}{|c|}{$\mathrm{F}$ and $\mathrm{S}^{1}$} & \multicolumn{2}{|c|}{$\mathrm{F}$ and $\mathrm{S} \mathrm{II}^{2}$} & \multicolumn{2}{|c|}{$\mathrm{H}$ and $\mathrm{F}^{3}$} \\
\hline & 1999 & 2003 & 1999 & 2003 & 1999 & 2003 \\
\hline \multicolumn{7}{|c|}{$\%$ of soil samples with $\sigma_{p}$ larger than the higher limit of the CI } \\
\hline Buritis & 0 & 0 & 0 & 0 & 0 & 20 \\
\hline Dourado & 8 & 0 & 17 & 0 & 17 & 0 \\
\hline S.Leonardo & 0 & 0 & 8 & 0 & 0 & 0 \\
\hline Average & 2.7 & 0 & 8.3 & 0 & 5.7 & 6.7 \\
\hline \multicolumn{7}{|c|}{$\%$ of soil samples with $\sigma_{p}$ between the lower and higher limit of the CI } \\
\hline Buritis & 75 & 80 & 83 & 20 & 75 & 40 \\
\hline Dourado & 92 & 100 & 83 & 100 & 66 & 100 \\
\hline S.Leonardo & 83 & 40 & 84 & 0 & 100 & 40 \\
\hline Average & 83.3 & 73.3 & 83.3 & 40 & 80.3 & 60 \\
\hline
\end{tabular}

$\%$ of soil samples with $\sigma_{\mathrm{p}}$ smaller than the lower limit of the CI

\begin{tabular}{lrrrrrr}
\hline Buritis & 25 & 20 & 17 & 80 & 17 & 40 \\
Dourado & 0 & 0 & 0 & 0 & 17 & 0 \\
S.Leonardo & 17 & 60 & 8 & 100 & 0 & 60 \\
Average & 14.0 & 26.7 & 8.4 & 60 & 14.0 & 33.3 \\
\hline
\end{tabular}

$1-\mathrm{F}$ and $\mathrm{S}=$ Feller and Skidder with tires 30.5L.32, 2 - F and S II = Feller and Skidder with tires 66.43.00.26, $3-\mathrm{H}$ and $\mathrm{F}=\mathrm{Harvester} \mathrm{e}$ Forwarder. $\mathrm{CI}=$ Confidence Interval.

Table 9 - Classification of the soil samples, according Figure 2, using the preconsolidation pressure values determined after the harvest operations for a Typic Acrustox at 0.10-0.125 m depth (Rainy Season).

\begin{tabular}{|c|c|c|c|c|c|c|c|c|c|c|c|c|}
\hline \multirow[t]{3}{*}{ Project } & \multicolumn{2}{|c|}{$\mathrm{F}$ and $\mathrm{S}^{1}$} & \multicolumn{2}{|c|}{$\mathrm{H}$ and $\mathrm{F}^{2}$} & \multicolumn{2}{|c|}{$\mathrm{M}$ and $\mathrm{F}^{3}$} & \multicolumn{2}{|c|}{$\mathrm{F}$ and $\mathrm{C}^{4}$} & \multicolumn{2}{|c|}{$\mathrm{M}$ and $\mathrm{M}^{5}$} & \multicolumn{2}{|c|}{$\mathrm{PA}^{6}$} \\
\hline & \multicolumn{12}{|c|}{$\%$ of soil samples with $\sigma_{p}$ larger than the higher limit of the CI } \\
\hline & $\begin{array}{c}2000^{*} \\
2001 * *\end{array}$ & 2003 & 2000 & 2003 & $\begin{array}{l}2000 \\
2001\end{array}$ & 2003 & 2001 & 2003 & 2001 & 2003 & $\begin{array}{l}2000 \\
2001\end{array}$ & 2003 \\
\hline Imbaúbas* & 13 & 0 & 9 & 0 & 13 & 20 & - & - & - & - & 16 & 20 \\
\hline Aeroporto* & 9 & 40 & 58 & 0 & 35 & 0 & - & - & - & - & 16 & 20 \\
\hline Água Suja Encosta** & 0 & 0 & - & - & 25 & 0 & 0 & 0 & 0 & 0 & 25 & 20 \\
\hline Água Suja Baixada** & 0 & 20 & - & - & 0 & 20 & 0 & 0 & - & - & 25 & 0 \\
\hline Cajá Encosta** & 0 & 20 & - & - & 0 & 0 & 0 & 0 & 0 & 0 & 0 & - \\
\hline Cajá Baixada** & 0 & 20 & - & - & 0 & 20 & 0 & 0 & 0 & 0 & 50 & 40 \\
\hline C. Hosken Encosta** & 0 & 0 & - & - & 25 & 0 & 0 & 40 & 0 & 0 & 0 & 0 \\
\hline \multirow[t]{2}{*}{ Average } & 3.2 & 14.3 & 33.5 & 0 & 14.0 & 8.6 & 0 & 8.0 & 0 & 0 & 18.9 & 16.7 \\
\hline & \multicolumn{12}{|c|}{$\%$ of soil samples with $\sigma_{p}$ between the lower and higher limit of the CI } \\
\hline Imbaúbas & 87 & 80 & 87 & 100 & 81 & 80 & - & - & - & - & 84 & 60 \\
\hline Aeroporto & 91 & 60 & 42 & 60 & 65 & 100 & - & - & - & - & 84 & 80 \\
\hline Água Suja Encosta & 100 & 100 & - & - & 75 & 100 & 100 & 100 & 100 & 100 & 75 & 80 \\
\hline Água Suja Baixada & 100 & 80 & - & - & 100 & 80 & 100 & 100 & - & - & 75 & 100 \\
\hline Cajá Encosta & 100 & 80 & - & - & 100 & 80 & 100 & 100 & 100 & 100 & 100 & - \\
\hline Cajá Baixada & 100 & 80 & - & - & 100 & 80 & 100 & 100 & 100 & 60 & 50 & 60 \\
\hline C. Hosken Encosta & 100 & 100 & - & - & 25 & 60 & 75 & 20 & 25 & 80 & 100 & 100 \\
\hline Average & 96.8 & 82.9 & 64.5 & 80.0 & 78.0 & 82.9 & 95.0 & 84.0 & 81.3 & 85.0 & 81.1 & 80.0 \\
\hline
\end{tabular}

$\%$ of soil samples with $\sigma_{p}$ smaller than the lower limit of the CI

\begin{tabular}{lrrrrrrrrrrrr}
\hline Imbaúbas & 0 & 20 & 4 & 0 & 6 & 0 & - & - & - & - & 0 & 20 \\
Aeroporto & 0 & 0 & 0 & 40 & 0 & 0 & - & - & - & - & 0 & 0 \\
Água Suja Encosta & 0 & 0 & - & - & 0 & 0 & 0 & 0 & 0 & 0 & 0 & 0 \\
Água Suja Baixada & 0 & 0 & - & - & 0 & 0 & 0 & 0 & - & - & 0 & 0 \\
Cajá Encosta & 0 & 0 & - & - & 0 & 20 & 0 & 0 & 0 & 0 & 0 & - \\
Cajá Baixada & 0 & 0 & - & - & 0 & 0 & 0 & 0 & 0 & 40 & 0 & 0 \\
C. Hosken Encosta & 0 & 0 & - & - & 50 & 40 & 25 & 40 & 75 & 20 & 0 & 0 \\
Average & 0 & 2.8 & 2.0 & 20.0 & 8.0 & 8.5 & 5.0 & 8.0 & 18.7 & 15.0 & 0 & 3.3 \\
\hline
\end{tabular}

$1-\mathrm{F}$ and $\mathrm{S}=$ Feller and Skidder with tires 30.5L.32, 2- $\mathrm{H}$ and $\mathrm{F}=$ Harvester and Forwarder, 3- $\mathrm{M}$ and $\mathrm{F}=$ Motorized saw and Forwarder,

4- $\mathrm{F}$ and $\mathrm{C}=$ Feller and Clambunk, $5-\mathrm{M}$ and $\mathrm{M}=$ Motorized saw and Manual, 6- PA = Processing area, - indicated that no measurement was done. $*=$ soil sampling in $2000, * *=$ soil sample in $2001 . \mathrm{CI}=$ Confidence Interval. 
ues, determined after the traffic, smaller than the lower limit of the confidence interval (Tables 8 and 9), being these operations the ones that caused less soil compaction.

Considering that a reduction in the preconsolidation pressure values is an indicator of soil structure recover (Dias Junior, 2003), the preconsolidation pressures were then measured in 2003 in the soil samples collected at the same sites as they were collected in 1999, 2000 and 2001, to verify whether there was some natural recover of the soil structure indicated by a decrease in the percentage of soil samples with preconsolidation pressure values in the region with additional soil compaction or an increase in a percentage of soil samples with preconsolidation pressure values in the region where the preconsolidation pressure values determined after the traffic are smaller than the lower limit of the confidence interval. The preconsolidation pressure values measured in 2003 indicated that a natural recovery of the soil structure happened for all harvest operations made in the dry season and in the rainy season for the Harvester and Forwarder, Motorized Saw and Forwarder and Processing Area. This interpretation was applied for the regarded soil depth of $0.1-0.125 \mathrm{~m}$, which is very close to the soil surface. For deeper layers, one should be aware of the crushing of aggregates by compaction that can lead to a reduction of the preconsolidation pressure, which cannot be regarded as a structural recovery process.

Finally, the results obtained for the operations in the dry and rainy seasons might serve as an alert on the importance of knowing the soil bearing capacity at a specific moisture condition, in order to avoid soil compaction, mainly, when the harvest operations are accomplished in the rainy season. Thus, this model may be used as an auxiliary criterion in planning the harvest operations according to the soil bearing capacity which can be done by scheduling the operations or reducing the applied mechanical loads.

\section{CONCLUSIONS}

The traffic effects on the preconsolidation pressure in the dry season indicated that the soil compaction process was neither evident nor important.

The traffic effects on the preconsolidation pressure in the rainy season indicated that operations made with Harvester and Forwarder caused greater soil compaction, while the operations performed with Motorized Saw and Manual caused less soil compaction.

\section{ACKNOWLEDGMENTS}

To CNPq for the Productivity Research Grant and to CENIBRA for the financing support of this research.

\section{REFERENCES}

ARVIDSSON, J. Subsoil compaction caused by heavy sugarbeet harvesters in southern Sweden I. Soil physical properties and crop yield in six field experiments. Soil \& Tillage Research, v.60, p.67-78, 2001.

ARVIDSSON, J. Subsoil compaction by heavy sugarbeet harvesters in southern Sweden III. Risk assessement using a soil water model. Soil \& Tillage Research, v.73, p.77-87, 2003.

BOWLES, J.E. Engineering properties of soils and their measurements. 3.ed. New York: McGraw-Hill, 1986. 218p.

CANILLAS, E.C.; SALOKHE, V.M. A decision support system for compaction assessment in agricultural soils. Soil \& Tillage Research, v.65, p.221-230, 2002.

DEFOSSEZ, P.; RICHARD, G. Models of soil compaction due to traffic and their evaluation. Soil \& Tillage Research, v.67, p.41-64, 2002.

DIAS JUNIOR, M.S. Compression of three soils under long-term tillage and wheel traffic. East Lansing: Michigan State University, 1994. 114p. (Ph.D. - Dissertation).

DIAS JUNIOR, M.S. Compactação do solo. In: NOVAIS, R.F.; ALVAREZ V., V.H.; SCHAEFER, C.E.G.R. (Ed.). Tópicos em ciência do solo. Viçosa: SBCS, 2000. p.55-94.

DIAS JUNIOR, M.S. A soil mechanics approach study soil compaction In: ACHYUTHAN, H. (Ed.). Soil and soil physics in continental environment. Chenna: Allied Publishers Private, 2003. p.179-199.

DIAS JUNIOR, M.S.; PIERCE, F.J. A simple procedure for estimating preconsolidation pressure from soil compression curves. Soil Technology, v.8, p.139-151, 1995.

DIAS JUNIOR, M.S.; PIERCE, F.J. Revisão de literatura: O processo de compactação do solo e sua modelagem. Revista Brasileira de Ciência do Solo, v.20, p.175-182, 1996.

DIAS JUNIOR, M.S.; FERREIRA, M.M.; FONSECA, S.; SILVA, A.R.; FERREIRA, D.F. Avaliação quantitativa da sustentabilidade estrutural dos solos em sistemas florestais na região de Aracruz - ES. Revista Árvore, v.23, p.371-380, 1999.

DIAS JUNIOR, M.S.; GOMES, A.N.; ANDRADE, S.C.; AZEVEDO, M.R. Avaliação da sustentabilidade da estrutura de Argissolos em sistemas florestais. Revista Cerne, v.8, p.103-114, 2002.

DIAS JUNIOR, M.S.; LEITE, F.P.; WINTER, M.E.; PIRES, J.V.G. Avaliação quantitativa da sustentabilidade estrutural de um Latossolo Amarelo cultivado com eucalipto na Região de Peçanha - MG. Revista Árvore, v.27, p.343-349, 2003.

GARDNER, W.H. Water content. In: KLUTE, A. (Ed.) Methods of soil analysis. Part 1. 2.ed. Madison: ASA, 1986. p.493-544.

GUPTA, S.C.; HADAS, A.; SCHAFER, R.L. Modeling soil mechanical behavior during compaction. In: LARSON, W.E.; BLAKE, G.R.; ALLMARAS, R.R.; VOORHEES, W.B.; GUPTA, S.C. (Ed.) Mechanics and related processes in structured agricultural soils. Dordrecht: Kluwer Academic Publishers, 1989. p.137-152.

HOLTZ, R.D.; KOVACS, W.D. An introduction to geotechnical engineering. Prentice-Hall: Englewood Cliffs, 1981. 733p.

HORN, R.; FLEIGE, H. A method for assessing the impact of load on mechanical stability and on physical properties of soils. Soil \& Tillage Research, v.73, p.89-99, 2003.

HORN, R.; WAY, T.; ROSTEK, J. Effect of repeated tractor wheeling on stress/strain properties and consequences on physical properties in structured arable soils. Soil \& Tillage Research, v.73, p.101-106, 2003.

IMHOFF, S.; SILVA, A.P.; DIAS JUNIOR, M.S.; TORMENA, C.A. Quantificação de pressões para o crescimento das plantas. Revista Brasileira de Ciência do Solo, v.25, p.11-18, 2001.

LEBERT, M.; HORN, R. A method to predict the mechanical strength of agricultural soils. Soil \& Tillage Research, v.19, p.275-286, 1991.

SNEDECOR, G.W.; COCHRAN, W.G. Statistical methods. 8.ed. Ames: Iowa State University Press, 1989. 503p.

TAYLOR, D.W. Fundamentals of soil mechanics. New York: John Wiley \& Sons, 1948. 700p.

$\overline{\text { Received July 13, }} 2004$

Accepted April 01, 2005 